\title{
Achieving Organizational Commitment through HRM Practices: The Ghanaian Banking Sector Experience
}

\author{
Rosemary Boateng Coffie ${ }^{1}$, Kofi Agyenim Boateng ${ }^{2} \&$ Frank Coffie $^{3}$ \\ ${ }^{1}$ School of Business, Kwame Nkrumah University of Science and Technology, Ghana \\ ${ }^{2}$ School of Business, Department of Supply Chain and Information Systems, Kwame Nkrumah University of \\ Science and Technology, Ghana \\ ${ }^{3}$ Barclays Bank Ghana, Ghana \\ Correspondence: Rosemary Boateng Coffie, School of Business, Kwame Nkrumah University of Science and \\ Technology, Ghana. E-mail: framaygh@yahoo.co.uk
}

Received: March 3, 2018

Accepted: March 27, 2018

Online Published: April 18, 2018

doi:10.5539/ijbm.v13n5p171

URL: https://doi.org/10.5539/ijbm.v13n5p171

\begin{abstract}
Organizational Commitment indicates the degree to which HRM practices are able to cultivate emotional connection between firms and employee goals. This study sought to investigate the nature of the relationship between the implementation of HRM practices and organizational commitment in the banking industry in Ghana. Employing the three component model of Allen and Meyer as the underlying theory of organizational commitment, the researchers examined the six HRM practices in five selected commercial banks in Ghana. Adopting the quantitative method of research, a descriptive including a multiple regression analysis was used to analyze the existing relationship between the HRM practices and organizational commitment. Findings from the study revealed that affective and normative forms of commitment were preferred to continuance forms of commitment. Again whilst respondent's affective and normative commitment included performance based pay, communication and information sharing, training and development and rewards recognition, that of the continuance commitment also included communication, information sharing, recruitment and selection performance appraisal as well as rewards and recognition. The study concludes that there is a positive relationship between the implementation of HRM practices and organizational commitment. A further study is therefore suggested towards the conduct of a qualitative study in all banks in Ghana to consider the applicability of generalizability on the subject matter.
\end{abstract}

Keywords: organizational commitment, human resource practices, Ghanaian banking sector

\section{Introduction}

Organizational commitment is an index that signals the extent to which the human resource management practices (HRM) used within an institution is able to cultivate emotional connection between firms and employee goals (Ahmad \& Schroeder, 2003). This suggests that organizational commitment is an incorporeal outcome of HRM practices and consequently plays a key role in retaining employees and using their competencies to the fullest (Ahmad \& Schroeder, 2003:26). Likewise, Lew (2011) even puts it in a more better perspective when the author posits that a worker is more likely to be incentivized to carry out with his work roles if apportioned with adequate guidance through training and development, assessed through effective performance evaluation criteria and rewarded through a performance based system. This vivid illustration of the impact of human resource practices within organizational context clearly shows that its impact on employees' attitudes and behaviour cannot be easily overshadowed. Evidently, due to its ability in fostering strong connection between employees and organization, Wasti et al. (2016) argue that ever since the concept emerged in the early part of 1960s, it has become a great area of enquiry and concern for both organizational behavior scholars and human resource practitioners alike. Initially, originating from the USA (Becker, 1960; Mowday, Steers, \& Porter, 1979) and subsequently developed further by both Canadian and American scholars (e.g., Becker, 1992; Meyer \& Allen, 1991; Meyer \& Herscovitch, 2001; Klein, Molloy, \& Brinsfield, 2012) models and studies of workplace commitment have generally been adopted worldwide (Fischer \& Mansell, 2009; Meyer, et al., 2012).

0According to Dominguez (2011) the human component of an institution's resources are viewed to be very 
critical in determining organization performance outcomes. This suggests that how effective an organization goes about in managing its human resources will be very critical to an institution's survival whether being a state or private entity (Juhdi, Pa'wan, Hansaram, \& Othman, 2011). However, managing the human resources of a firm demands the application of bundle human resource practices (Ortega-Parra \& Sastre-Castillo, 2013) that play a key role in enabling institutions bring to bear an improved form of employees performance and attitudes they desire (Fong, Ooi, Tan, Lee, \& Chong, 2011; Lew, 2011).

Empirically, it has been confirmed that the bundle of human resource management practices an organization implements have a significant impact in predicting employees' emotional attachment to its organization (Fong et al., 2011; Alkalha, Al-Zu'bi, Al-Dmour, \& Alshurideh, 2012; Vratskikh, Al-Lozi, \& Maqableh, 2016). However, as argued by Wasti et al. (2016) there are still enough reasons for additional studies to be carried out to comprehend the likely variations among countries and firms with regards to organizational commitment outcomes on employees' behaviour. The call for further studies in organization commitment has become necessary since prior studies were either carried out in welfare economies of northern Europe or the liberal market economies of North America with no much emphasis to institutions in the Sub-Saharan Africa region. For instance, Cohen and colleagues have extensively studied predictors of employees' commitment as well as organizational commitment impact on employee turnover intentions mainly among Israeli Arabs and Jewish employees (see for example, Cohen, 1998; Cohen, 1999; Cohen, 2007; Cohen, 2010; Cohen \& Liu, 2011). Also, within the context of Denmark, Jørgensen and colleagues have likewise extensively studied organizational commitment construct within both Danish public and private organizations (see for example, Jørgensen \& Sluhan, 2013; Jørgensen \& Becker, 2015). Again within the context of Latin America e.g. Brazil, Rodrigues' et al. (2013) explores organizational commitment issues across samples ranging from rural to urban, high to low education, and public to private sector entities (see for example, Rodrigues, Gondim, Bastos, \& Sakamoto, 2013). More so, Weng and others have carried out much work with reference to organizational commitment in different regions of China and states within the US (see for e.g. Weng, McElroy, Morrow, \& Liu, 2010; Weng \& McElroy, 2012; Weng \& Xi, 2013).

Within the context of Ghana it appears no attention has been given to HRM practices and organizational commitment. The only study in the Ghanaian context that appears to have dealt with this area is the work of Dartey-Baah (2014). Even with the said work, its objective was to mainly assess the impact of fairness perception in firms' policy implementation on workers' job satisfaction, work motivation and organizational commitment but not to measure the relationship between HRM practices and organizational commitment. It is against this backdrop that this study seeks to measure the relationship between HRM practices and organizational commitment by measuring the impact from the banking system of Ghana. Therefore, the main objective of the study is to investigate the relationship between human resource practices and organizational commitment.

\section{Literature Review}

\subsection{Organizational Commitment}

With time several scholars have attempted to provide a conceptualized model to understudy the concept of organizational commitment within institutions. However, among all the numerous theories for conceptualizing organizational commitment, the three component model (TCM) of Meyer and Allen (1991) has become the predominant theory for understudying the concept (Klein, Molloy, \& Brinsfield, 2012). To authors like Meyer and Herscovitch (2001), Fischer and Mansell (2009), Üsdiken and Wasti (2009) and Meyer et al. (2012), Meyer and Allen's TCM have been widely adopted and employed across several contexts. This suggests that the model suitability across different geographical context have been greatly confirmed and well accepted by all. Accordingly, the present study employs Allen and Meyer's (1991) TCM as its theoretical framework. According to Meyer, Becker and Vandenberghe (2004) commitment is a bond that connects an entity or individual to a social or non-social group or to a given course of action. To Wasti et al. (2016) this emotional connection can be experienced in different forms hence could take the form of an affective attachment to an entity (i.e. affective commitment), an awareness of the costs associated with discontinuing involvement with an entity (i.e. continuance commitment) and a felt obligation towards a social group or entity (i.e. normative commitment).

With particular reference to affective form of commitment, Cho and Huang (2012) described it as the internalization as well as the emotional connection an individual has towards his organization largely because the said individual enjoys membership in an organization and is voluntarily willing to exert effort on that entity's behalf. Accordingly, employees with strong affective form of commitment want to remain with an organization. Moreover, firms can build affective commitment by ensuring open communication, increasing employees' access 
to information and giving employees the chance to participate in the firms or department decision making (Suma \& Lesha, 2013).

With normative commitment, it mostly becomes evident when a person feels that he/she has to be with an institution mainly because of what the organization has done for him through organizational support programs or systems (Sayğan, 2011). To Cho and Huang (2012), normative commitment entails the perceived obligations to maintain employment relationships with a social entity mainly because of what an organization has provided to an employee over time. Hence, in exchange for employment, employees feel compelled to reciprocate with their loyalty and commitment (Meyer \& Herscovitch, 2001). Again, the normative commitment is synonymous with the social exchange theory which is based on the reciprocity principles within social relationships. Hence, it argues that employees who receive economic or socio-emotional benefits from their organization feel obligated to respond in kind or remain with their employer (Eisenberger, Huntington, Hutchison, \& Sowa, 1986; Rhoades \& Eisenberger, 2002).

The third form of commitment is continuance commitment (CC), which involves appraisals of personal investments tied to one's current employment and the availability of employment alternatives (Meyer \& Allen, 1991). Employees with strong CC maintain their employment relationship because it provides them with desirable personal outcomes that they are unwilling to forego or because they perceive a lack of employment opportunities elsewhere (Riveros \& Tsai, 2011; Cho \& Huang, 2012). This form of commitment suggests that a worker maintains his/her membership with a social entity as a way to preserve his accrued benefits (for example, pension, seniority packages, defined benefit packages, etc.) or for fear of non-availability of employment opportunities in the job market.

\subsection{HRM Practices and Organizational Commitment}

As stated earlier, the bundle of human resource management practices an organization puts into practice has an enormous impact in fostering organizational commitment among its workforce (see for example, Fong et al., 2011; Alkalha, et al., 2012; Vratskikh et al. 2016). Accordingly, this section seeks to identify the nature of relationship that exist between HRM practices (recruitment and selection, training and development, appraisal of performance, communication and information sharing, as well as compensation and reward) and organizational commitment (affective commitment, normative commitment and continuance commitment).

\subsubsection{Performance Based Pay and Organizational Commitment}

According to Paşaoğlu (2015) often times, employees working in organizations that offer lucrative compensation packages believe that such institution values their output hence are willing to provide its workers with adequate compensation plans that will be able to meet their individual needs. Empirically, it has been reported that organizations that provide its workers with a performance based compensation get in return committed employees who are willing to keep their employment arrangement with their employer for a long run. Hence, Meyer and Allen (1997) reported a strong relationship between performances based pay and continuance commitment. Likewise, Paşaoğlu (2015) recorded a significant positive relationship between performance base pay and organizational commitment among banking population within Turkey. Also, Gellatly, Hunter, Currie and Irving (2009) posited a significant relationship between firms compensation packages and employees affective and continuance commitment towards their organization. Likewise, Blau, Merriman, Tatum and Rudmann (2001) reported a significant relationship between performance based compensation and organizational commitment. In contrast, in the studies of Fiorito, Bozeman, Young and Meurs (2007) it became evident that performance based compensation are negatively related to organizational commitment.

\subsubsection{Recruitment and Selection and Organizational Commitment}

Recruitment is the process of generating a pool of capable applicants to apply for employment positions within an organisation whiles selection is the process by which specific instruments are used to choose from a pool of applicants' persons most suitable for a job taking into accounts management goals and state's legal requirements (Bratton \& Gold, 2003). In the works of Qiao et al. (2008) it became evident that an organization recruitment and selection processes had a significant impact on employees' organizational commitment. Also, Cho, Woods, Jang, and Erdem (2006) assessed pre-employment tests used in the selection process and found out that its application are in some way able to select workers that have the enthusiasm to stay with a company longer. This suggests that passing pre-employment tests gives an applicant a stronger sense of belonging to the company, resulting in higher degrees of organizational commitment.

\subsubsection{Training and Development and Organizational Commitment}

Rhoades and Eisenberger (2002) argue that providing training and development opportunities to an organization 
workforce sends strong signals to the employees that their employers care about their growth and also value their progression too. It has been empirically validated that training and development programs do not only develop employees and augment their skills and abilities, but also enhance their satisfaction towards their job and commitment towards their organisation (McElroy, 2001; Paul \& Anantharaman, 2004). Qiao et al. (2008) on the other hand measured the influence of HRM practices on organizational commitment. Evidently, their study results reported a significant relationship between training and development and organizational commitment. Likewise, Gellatly et al. (2009) found out that employee perceptions of development-oriented HR practices such as training and development ensured a positive employee affective and continuance commitment towards their organization. Same revelation was likewise confirmed in the studies of Paşaoğlu (2015) when the author study results reported a significant relationship between training and development and organizational commitment.

\subsubsection{Communication and Information Sharing and Organizational Commitment}

The information sharing process involves the way an organisation sends and receives information among its workforce in order to strengthen the decision making process (Özgan, 2011). This practice ensures that employees are being recognized members in the organization decision making process and such practice sends a signal to the employees that management respect their views and values their participation. Empirically, Meyer and Smith (2009) reported that information sharing is positively correlated to affective commitment by building management-employee trust and workers' self-worthiness. Equally, Guzley (2001) confirmed this relationship, stating that open and transparent communication together with access to adequate information and participative decision making style build strong affective commitment among organization workforce. Also, Qiao et al. (2008) found a significant relationship between communication and information sharing and organizational commitment. Additionally, Fiorito et al. (2007) and Giauque, Ritz, Varone and Anderfuhren-Biget (2010) study results showed employee involvement (measured by employees' ability to communicate and share their views in an organization decision making process) was found to be positively correlated to organizational commitment.

\subsubsection{Performance Appraisal and Organizational Commitment}

According to DeCenzo and Robbins (2013) performance appraisals are used for three main purposes namely; giving feedback about a worker performance to both the worker and his organization; used as a tool to develop employee's skill gap and improve their performance; and used as a term of reference for future decision purposes. In other instances, performance appraisals are used by organizations to guide their compensation packages and promotion decisions (Sripirabaa \& Krishnaveni, 2009). ) Giauque et al. (2010) in their studies, assessed how the various HRM practices implemented by Swiss's SMEs firms impacted on their employees' commitment. Results from their study showed that the procedural justice in the firms' performance appraisal processes affected the respondents' commitment levels. Also, in the study of Paşaoğlu (2015), it became evident that performance appraisal had a significant positve relationship with organizational commitment. Likewise, Paul and Anantharaman (2004) reported similar observations in their study when their study results revealed a significant relationship between performance appraisal practices and organisational commitment.

\subsubsection{Rewards and Recognition and Organizational Commitment}

Notably, before one engages in any activity, every individual consciously or subconsciously asks the same question, what will I get out of this? Psychologists have recognized for a long time that satisfaction of needs is the motivation behind all actions. This satisfaction or reward might be money, promotion, recognition, acceptance, receipt of information, or a feeling that comes from doing a good job. Monetary compensation is important, but not sufficient, to keep employees hence, the non-monetary aspect of compensation plays a significant role in the workers behaviour and attitudes. Correspondingly, Paré and Tremblay (2007) in their work postulated that recognition is positively related to continuance and affective commitment. On another breadth, McEnroe and Hechler (1985) found a positive relationship between rewards and recognition and organisational commitment. However, Meyer and Smith (2000) argued that the ability of a firm's rewards and recognition practices to bring about affective and normative commitment were to a great extent influenced by perceptions of procedural justice attached to the implementation of this HR practice. Likewise, Giauque et al. (2010) corroborated Meyer and Smith (2000) position as well when their findings showed that firms HRM practices impact on organizational commitment become only evident when the recipients of these firm's policies perceive the processes for its implementation as fair, just and devoid of any favouritism.

\section{Methods}

The study measured the understudied firms HRM practices using six HR practices namely; performance based pay, recruitment and selection, training and development, communication and information sharing, performance appraisal and reward and recognition. On these items, the study used a five-point scale rating thus, 1-strongly 
disagree to 5-strongly agree to elicit the respondents' responses as to whether these HRM practices were implemented at the five banking institutions. The study used scales of previous studies (for example, Pfeffer, 1998; Gould-Williams, 2003; Boselie, 2010; Gould-Williams \& Gatenby, 2010; Kehoe \& Wright, 2013) to measure the enlisted six HRM practices. In all, the six HRM practices had 30 items thus, performance based pay had 5 items, recruitment and selection had 6 items, training and development had 5 items, communication and information sharing had 5 items, performance appraisal had 4 items and finally reward and recognition had 5 items. Specifically, for the relationship analysis, the study employed simultaneous multiple regression to analyse the relationship that existed between the six HRM practices and the three organizational commitment dimensions.

However, on the organizational commitment construct the study adopted the three commitment model of Allen and Meyer (1990). In all 18 measuring items, based on a five-point Likert scale (i.e. 1-stronlgy disagree to 5 -strongly agree) was used to elicit respondents' level of commitment towards their organization. It contained items on all the three commitment dimensions namely; affective commitment, normative commitment and continuance commitment. Moreover, the Cronbach's alpha value for both the HRM practices constructs and organizational commitment constructs have been presented in Table 1 and 2 respectively.

Table 1. Reliability of HR practices

\begin{tabular}{ll}
\hline HRM Practices & Cronbach Alpha \\
\hline Performance based pay & 0.894 \\
Communication and information sharing & 0.937 \\
Recruitment and selection & 0.843 \\
Training and development & 0.622 \\
Performance appraisal & 0.841 \\
Recognition and rewards & 0.816 \\
\hline
\end{tabular}

Source: Author's Fieldwork, 2018.

The reliability (internal consistency) of the items comprising each construct was examined using Cronbach's alpha. The first HR practice, labelled 'performance based pay' measuring the pecuniary remuneration employees received from their output had a Cronbach alpha value of 0.894 . The second HR practice, labelled 'communication and information sharing' measuring how information was being transferred from top management to lower employee and vice versa had a Cronbach alpha value of 0.937. The next HR practice, labelled 'recruitment and selection' measuring the processes used to recruit and select new employees within their organisation recorded a Cronbach alpha value of 0.843 . The fourth HR practice, labelled 'training and development measuring how training and development programmes were implemented and its effectiveness had a Cronbach alpha value of 0.622 . The fifth HR practice, labelled 'performance appraisal' measuring how employee's performance appraisals systems were implemented within their organisation recorded a Cronbach alpha value of 0.841 . The last HR practice, labelled 'recognition and rewards' measuring how employees were being recognised and rewarded by their employers had a Cronbach alpha value of 0.816 .

Table 2. Reliability of organisational commitment

\begin{tabular}{ll}
\hline OC & Cronbach Alpha \\
\hline Affective commitment & 0.841 \\
Normative commitment & 0.865 \\
Continuance commitment & 0.794 \\
\hline
\end{tabular}

Source: Author's Fieldwork, 2018.

With the organizational commitment construct, the affective commitment scale had six items measuring the emotional reasons for which employees would stay with their employer. The resulting Cronbach alpha for affective commitment was 0.841 . The continuance commitment scale included six items measuring the economic reasons for which employees would stay in the organization. The resulting Cronbach alpha for continuance commitment was 0.794 . Finally, the normative commitment scale included six items measuring the ethical and the moral reasons for which employees would stay in their organization. The resulting Cronbach alpha for 
normative commitment was 0.865 . Subsequently, the descriptive statistics were analysed by a mean and standard deviation whereas the multiple regression was used for the relationship analysis.

A projected population size of 300 employees from five commercial banks were identified as the population for this study. The target population for this study consisted of all employees in the five most profitable commercial banks operating within the Kumasi Metropolis. Measurement of their profitability was based on the PwC Ghana banking survey report, 2017 using the banks' Profit before Tax margin (PBT) as the selection criteria. The first 5 banks with the high PBT were selected to participate in this study. With the distribution of the questionnaire the study employed an online survey platform specifically Google forms to design the questionnaire for distribution. Hereinafter the link to the designed questionnaire were sent to the targeted respondents via their email when provided or via their phones. In all the study distributed a total of 250 questionnaires through this process. Out of the distributed questionnaires, 125 were received of which 100 were usable for the study analysis giving a response rate of $44.44 \%$.

\section{Results}

The descriptive statistics about the demographic profile of the respondents have been presented in Table 3 .

Table 3. Demographic profile of the respondents

\begin{tabular}{llll}
\hline Demographic variable & Category & Frequency & Percent \\
\hline Age & $21-30$ & 15 & 15.0 \\
& $31-40$ & 63 & 63.0 \\
& $41-50$ & 22 & 22.0 \\
Gender & Male & 78 & 78.0 \\
& Female & 22 & 22.0 \\
Educational qualification & & & \\
& Degree & 50 & 50.0 \\
Position & Post-Degree & 50 & 50.0 \\
& & & \\
& Managerial & 23 & 23.0 \\
\hline
\end{tabular}

Source: Author's field source, 2018.

Results from the demographic profile revealed that most of the respondents' ages fell within the age bracket of 31-40 years. Also, with reference to the respondents' gender status, more than half of the respondents were males. However, for the respondents' educational background, most of them either had a bachelor's degree or master's degree as their academic qualification and finally most of the respondents were employed in non-managerial roles at the understudied banks.

However, with the main measures of the study, the descriptive statistics of the six human resource practices have been presented in Table 4.

Table 4. HRM practices available in banks

\begin{tabular}{lll}
\hline HRM Practices & Mean & SD \\
\hline Performance based compensation & 2.83 & 1.011 \\
Communication and Information Sharing & 3.56 & 0.988 \\
Recruitment and selection & 3.33 & 0.978 \\
Training and development & 3.73 & 1.133 \\
Performance Appraisal & 3.61 & 1.123 \\
Recognition and reward & 3.33 & 0.858 \\
\hline
\end{tabular}

Source: Author's field source, 2018.

The descriptive statistics in Table 4 reveal that out of the six HRM practices investigated, 3 were found to be employed by the understudied banks whereas the remaining three were found not be wholly applied by the 
surveyed firms in their employee's management. Accordingly, the respondents agreed that HRM practices such as communication and information sharing, training and development and performance appraisal were the main HRM practices used within their firms. This suggests that on the communication and information sharing practice, the surveyed banks informed their employees regularly on possible future bank projects as well how the banks performance fared in the previous year. Also, on training and development practice, findings from the study suggest that the surveyed banks offered their workers opportunities for training and development as well as provided workers the opportunities for personal skills development. Similarly, on performance appraisal practice, findings from the study revealed that extensive processes were used by the surveyed banks to assess their staffs' performance. Also, on this same HR practice the banks ensured that feedback was given to their employees after every performance appraisal exercise. However, with the other HRM practices results from the study could not confirm whether the surveyed banks fully practiced performance based compensation, recruitment and selection, reward and recognition as part of their HR practices. On these HRM practices results from the study suggests that the respondents were neutral in their responses. That is, respondents could neither agree nor disagree to the existence of these HRM practices in their organizations'.

\subsection{Relationship between Respondents' Demographic Profile and Organization Commitment}

The regression analysis of the relationship between the respondents' demographic profile (i.e. age, gender, educational status and respondent position within an organization) and the three organizational commitment constructs have been presented in Table 5 .

Table 5. Relationship between demographic profile and organizational commitment

\begin{tabular}{|c|c|c|c|c|c|}
\hline Variables & Unstandardized coefficient & Standard error & R Square & Adjusted R square & Significance level \\
\hline Affective commitment & & & .786 & .777 & .000 \\
\hline $\mathrm{Ag}$ & 6.417 & .386 & & & .000 \\
\hline Gend & 2.579 & .510 & & & .000 \\
\hline Edu. qual. & -4.638 & .438 & & & .000 \\
\hline Pos. & -4.171 & .448 & & & .000 \\
\hline Normative commitment & & & .491 & .470 & .000 \\
\hline $\mathrm{Ag}$ & 1.292 & .692 & & & .065 \\
\hline Gend & 1.873 & .917 & & & .044 \\
\hline Edu. qual. & -.439 & .760 & & & .565 \\
\hline Pos. & -7.500 & .835 & & & .000 \\
\hline Continuance commitment & & & .389 & .363 & .000 \\
\hline $\mathrm{Ag}$ & 4.127 & .691 & & & .000 \\
\hline Gend & .384 & .916 & & & .676 \\
\hline Edu. qual. & .363 & .759 & & & .633 \\
\hline Pos. & -4.340 & .835 & & & .000 \\
\hline
\end{tabular}

Dependent Variable: Organizational commitment (Affective commitment, Normative commitment and Continuance commitment)

Predictors: Demographic profile Age (Ag.), Gender (Gend), Educational qualification (Edu. qual) Position held (Pos)

Source: Author's field work, 2018

The multiple regression results in Table 5 reveal that the respondents demographic profile (i.e. age, gender, educational qualification and position held) had a significant impact on affective commitment since $p<0.000$. The Adjusted R square value under the affective commitment is 0.777 suggesting that $78 \%$ of the variance in the respondents' affective attachment to their organization could be explained by their demographic characteristics. Under the affective commitment scale, all the demographic characteristics measured had a significant impact on the respondents' affective commitment.

Moreover, with normative commitment dimension, results from Table 5 show that there is significant relationship between respondents' demographic profile and normative commitment since $p<0.000$. However, the Adjusted R square value for the normative commitment construct was 0.470 meaning $47 \%$ of the variability in this commitment construct can be explained by the measured demographic characteristics. On the normative commitment construct, the demographic characteristics that had a significant impact on the respondents' normative commitment were; gender and position held in the organization. Evidently, these two demographic profile recorded $\mathrm{p}$ value of $<0.000$. In contrast, a respondent age and educational background were found to have 
no significant impact on the respondents' normative commitment since the $\mathrm{p}$ value for these two demographic characteristics were $>0.05$.

Lastly, with continuance commitment dimension, results from Table 5 reveal that there is significant relationship between respondents' demographic profile and continuance commitment since $p<0.000$. Nevertheless, the Adjusted R square value for the continuance commitment construct stood at 0.363 meaning only $36.3 \%$ of the variability in the respondents' continuance commitment can be predicted by their demographic profile.

Specifically, on the continuance commitment the key demographic variable that had a significant relationship on the respondents' continuance commitment were age and position held. These two demographic profile recorded $\mathrm{p}$ value of $<0.000$. On the other hand, respondents demographic profile such as; gender and educational qualification reported an insignificant relationship with continuance commitment since the $\mathrm{p}$ value was $>0.05$.

\subsection{Relationship between HRM Practices and Organization Commitment}

The regression analysis of the relationship between the understudied HRM practices and the three organizational commitment constructs have been presented in Table 5.

Table 6. Relationship between HRM practices and organizational commitment

\begin{tabular}{|c|c|c|c|c|c|}
\hline Variables & Unstandardized coefficient & Standard error & R Square & Adjusted R square & Significance level \\
\hline Affective commitment & & & .725 & .704 & .000 \\
\hline $\mathrm{PBC}$ & .297 & .080 & & & .000 \\
\hline C \& I S & .481 & .138 & & & .001 \\
\hline Rec. \& Sel. & -.370 & .208 & & & .079 \\
\hline Trn. Dev. & .409 & .128 & & & .002 \\
\hline $\mathrm{PA}$ & -.191 & .216 & & & .377 \\
\hline Rec. \& Rew. & .298 & .130 & & & .024 \\
\hline Normative commitment & & & .804 & .789 & .000 \\
\hline Р B P & .739 & .087 & & & .000 \\
\hline CIS & -.281 & .149 & & & .064 \\
\hline Rec. \& Sel. & .956 & .226 & & & .000 \\
\hline Trn. \& Dev. & -.143 & .139 & & & .308 \\
\hline $\mathrm{PA}$ & -.242 & .234 & & & .303 \\
\hline Rec. \& Rew. & 1.215 & .141 & & & .000 \\
\hline Continuance commitment & & & .810 & .795 & .000 \\
\hline $\mathrm{PBC}$ & -.006 & .077 & & & .936 \\
\hline CIS & .740 & .131 & & & .000 \\
\hline Rec. \& Sel. & -.911 & .199 & & & .000 \\
\hline Trn. \& Dev. & .010 & .123 & & & .933 \\
\hline $\mathrm{PA}$ & .943 & .206 & & & .000 \\
\hline Rec. \& Rew. & .323 & .124 & & & .011 \\
\hline
\end{tabular}

Dependent Variable: Organizational commitment (Affective commitment, Normative commitment and Continuance commitment)

Predictors: HRM practices (Recognition and Rewards (Rec. Rew.), Performance Based Pay (PBP), Performance Appraisal (PA), Communication and Information Sharing (CIS), Training and Development (Trn. Dev.), Recruitment and Selection (Rec. Sel.)

Source: Author's field work, 2018

The multiple regression results in Table 2 shows that the understudied HRM practices have a significant impact on affective commitment since $p<0.000$. The Adjusted $\mathrm{R}$ square value under the affective commitment is 0.74 suggesting that $70.4 \%$ of the variance in the respondents' affective attachment to their organization could be explained by the human resource practices. Under the affective commitment scale, the main HRM practices that had a significant impact on the respondents' affective commitment were; performance based pay, communication and information sharing, training and development and rewards and recognition. All these HRM practices recorded $\mathrm{p}$ value of $<0.000$. In contrast, HRM practices such as; recruitment and selection and performance 
appraisal recorded an insignificant relationship with the affective commitment since the $\mathrm{p}$ value for these two HRM practices $>0.05$.

Subsequently, with normative commitment construct, results from Table 2 show that there is significant relationship between the HRM practices and normative commitment since $p<0.000$. However, the Adjusted $\mathrm{R}$ square value for the normative commitment construct was 0.789 meaning $78.9 \%$ of the variation in this commitment construct can be explained by the understudied human resource practices. Also, under the normative commitment construct, the key HRM practices that recorded a significant impact on the respondents' normative commitment were; performance based pay, recruitment and selection, and rewards and recognition. All these three HRM practices recorded $\mathrm{p}$ value of $<0.000$. In the reverse, HRM practices such as; communication and information sharing, training and development and performance appraisal recorded an insignificant relationship with normative commitment since the $\mathrm{p}$ value for these HRM practices $>0.05$.

Finally, with continuance commitment scale, results from Table 2 show that there is significant relationship between the understudied HRM practices and continuance commitment since $p<0.000$. Nonetheless, the Adjusted R square value for the continuance commitment construct was 0.795 suggesting that $79.5 \%$ of the variability in the respondents' continuance commitment can be predicted by the understudied human resource practices.

Specifically, the main HRM practices that recorded a significant impact on the respondent's continuance commitment were; communication and information sharing, recruitment and selection, performance appraisal and rewards and recognition. All these four HRM practices recorded $p$ value of $<0.000$. On the other hand, HRM practices such as; performance based pay and training and development reported an insignificant relationship with continuance commitment since the $\mathrm{p}$ value was $>0.05$.

\section{Discussions}

Results from the study show that a respondent demographic profile had a significant impact on the type of organizational commitment dimension a respondent espoused towards his organization. Evidently, a respondent position occupied within an organization as well as his age were found to have a significant impact on his continuance commitment. This suggests that once a person's role within an organization gets to a top management level such an employee may feel he/she has come a long way in the organization's hierarchy hence, may not be willing to leave his employer for any other employer due to perceived benefits he may be enjoying from his present role. Additionally, the continuance commitment attached to this demographic profile can also be linked to the opportunity cost an employee may see himself to lose if he decides to leave his top position to go and start afresh with a new organization. Also, as one age increases his desire to look for new employment opportunities elsewhere dwindles since generally, the perception is that employers prefer young employees for entry jobs hence, recording a significant relationship between age and continuance commitment affirm this old held view. Moreover, findings from the study show that the respondents affective commitment were influenced by their age, gender, educational qualification and position held at their organization.

Accordingly, findings from this study is consistent with the works of Pala, Eker and Eker (2008) and Affum-Osei, Acquaah and Acheampong (2015) which reported a significant relationship between respondent demographic profile (i.e. gender, education, experience, title and institution) and organizational commitment. Additionally, findings from this study is in line with the works of Sepahvand, Atashzadeh-Shoorideh, Parvizy and Tafreshi (2017) which established that a person's demographic profile of particular years of work experience and position held within an organizaton has a significant relationship with continuance commitment. Likewise, findings from this study corroborate the study results of Carman (2011), Siew, Chitpakdee and Chontawan (2011) and Jafari, Afshin, Jafari and Barzegar (2015) which all posited a significant relationship between a respondent's age and organizational commitment. Similarly, findings from this affirm the earlier works of Larber and Savis (2014) and Seyedin et al. (2013) which all established an insignificant relationship between a respondent's educational status and normative and continuance commitment.

In contrast, findings from this study is inconsistent with the works of Sepahvand et al. (2017), Seyedin, Zaboli, Malmoon and Azami (2013) and that of Samadi and Mahdavikhou (2009) which reported an insignificant relationship between a person's age and organizational commitment.

Evidently, the bundle of human resource practices a firm decides to implement for its workforce will have a consequential effect on the kind of commitment its employees are likely to demonstrate towards their organization. Moreover, as stated earlier, a person's commitment towards a social entity could either take the form of an affective type, normative or continuance type. This suggests that commitment as explained in the work of Meyer and Allen (1991) three component model may not connote the same result to the same effect due 
to the differences in these commitment types. Explicitly, affective commitment and normative form of commitment are more preferred than continuance form of commitment since extant literature suggests that the former form of commitment produces positive employee's discretionary outcomes (see for example; Eisenberger, Huntington, Hutchison, \& Sowa, 1986; Meyer \& Herscovitch, 2001; Rhoades \& Eisenberger, 2002; Sayğan, 2011; Cho \& Huang, 2012).

Again findings from the study suggests that the main HRM practices that predicted the respondents affective form of commitment were performance based pay, communication and information sharing, training and development and rewards and recognition. On this score findings from this study is consistent with the earlier works of Gellatly et al. (2009) which established a significant relationship between firms' compensation packages and affective commitment. Likewise, findings from this study affirmed the works of Gellatly et al. (2009) which reported a significant relationship between training and development and affective commitment. Additionally, findings from this study corroborate the study results of Meyer and Smith (2009) which revealed that information sharing is positively correlated to affective commitment. Arguably, when employees perceived that management or their superiors always keep them informed about their firm's activities, they come to appreciate that their organization value them and respect their views as such. Hence, this HRM practice if continuously implemented builds mutual respect between management and employees. Hence, this act of participation and information sharing enables employees feel part of their organization therefore more likely to be more emotionally attached to what their institutions seek to do or achieve. This suggests that an organization characterized by open and transparent communication system together with ensuring access to adequate information produces positive affective commitment among organization workforce (Guzley, 2001).

More so, as Suma and Lesha (2013) assert that a firm build its employees' affective commitment by ensuring open communication, increasing access to information and giving employees the chance to participate in the firm's or department's decision making. Accordingly, findings from this work corroborate the works of Guzley (2001) and that of Suma and Lesha (2013) in this regard. Likewise, results from this study is in line with that of Paré and Tremblay (2007) which postulated that reward and recognition is positively related to affective commitment.

Also, with reference to the HRM practices that predicted respondents' normative commitment, performance based pay, recruitment and selection and rewards and recognition had a significant impact on normative commitment. Findings from this work is in tandem with the works of Paşaoğlu (2015) which recorded a significant relationship between performance-based pay and organizational commitment. Also, findings from this study affirmed the earlier views of Cho et al. (2006) which posited that the employees who went through a rigorous selection processes before gaining employment with a particular institution feels a moral obligation to keep their employment relationship with their organization largely because they feel the employer went through a lot before identifying or selecting them.

Again findings from this study which reported a significant relationship between rewards and recognition and normative commitment is consistent with the studies of Meyer and Smith (2000) which likewise established a significant relationship between the firm's rewards and recognition practice and normative commitment.

Results from the study revealed a significant relationship between communication and information sharing, recruitment and selection, performance appraisal, rewards and recognition and continuance commitment. On this score, findings from this study confirmed the findings of Qiao et al. (2008) which revealed that an organization recruitment and selection processes had a significant impact on employees' organizational commitment. Again findings from this study affirmed the works of Fiorito et al. (2007) and that of Giauque et al. (2010) which all in their respective studies reported a significant relationship between communication and information sharing practice and organizational commitment. Finally, findings from this study is in line with that of Paré and Tremblay (2007) which study results opined a significant relationship between rewards and recognition and continuance commitment. Having a significant relationship between rewards and recognition and continuance commitment affirms the views of Riveros and Tsai (2011) who argue that desirable personal outcomes such as seniority pay, bonuses, and other defined benefit packages within an institution increase employees continuance commitment to a given entity mainly because employees in such situations are unwilling to forego such benefits. This suggests the surveyed respondents are in some way only trying to maintain their employment relationship with their employer in order to protect their accrued side-bets.

\section{Conclusions}

Results from the study show that through implementation of bundle of human resource practices, firms are able to increase their employees' emotional attachment to their organization. Accordingly, employees perceive the 
provision of training and development programs as a form of investment done by their employers to build their skills and competencies for future roles. Hence, when such human resources are being provided at a workplace employees tend to have a positive orientation towards their organization and in so doing willing to keep working with such an entity. Again results from the study show that when organization provides their employees with good rewards and recognition packages, compensation and performance evaluation systems, morally they feel obliged to keep their employment contract with such an organization. Hence, in exchange for employment, employees feel compelled to reciprocate such organizational policies with their loyalty and commitment.

\section{Limitations and Further Studies}

Findings from this study used only six HRM practices therefore its findings may not be exhaustive to cover all the various HRM practices hence, over generalization of findings of this study should be used with care. Again, this study confined itself to the five most profitable commercial banks in Ghana therefore, its findings may not be a true reflection of what happens at the other remaining banks within the country. Finally, findings from the study revealed that an organization's HRM practices if well implemented will have a great impact in moderating its workforce commitment, on this note it is recommended that the banking organization should pay attention to certain HRM practices such as employee engagement since its practice will send a positive signal to its workforce that their organization cares about their wellbeing. The researchers recommend the conduction of the study in a qualitative from in all commercial banks in Ghana to merit generalization in the banking industry on the subject matter.

\section{References}

Affum-Osei, E., Acquaah, E., \& Acheampong, P. (2015). Relationship between Organisational Commitment and Demographic Variables: Evidence from a Commercial Bank in Ghana. American Journal of Industrial and Business Management, 5, 769-778. http://dx.doi.org/10.4236/ajibm.2015.512074

Ahmad, S., \& Schroeder, R. G. (2003). The impact of human resource management practices on operational performance: recognizing country and industry differences. Journal of Operations Management, 21, 19-43.

Alkalha, Z., Al-Zu'bi, Z., Al-Dmour, H., \& Alshurideh, M. (2012). Investigating the effects of human resource policies on organizational performance: An empirical study on commercial banks operating in Jordan. European Journal of Economics, Finance and Administrative Sciences, 51(1), 44-64.

Becker, H. S. (1960). Notes on the concept of commitment. American Journal of Sociology, 66, 32-42.

Becker, T. E. (1992). Foci and bases of commitment: are they distinctions worth making? Academy of Management Journal, 35, 232-244.

Blau, G., Merriman, K., Tatum, D. S., \& Rudmann, S. V. (2001). Antecedents and consequences of basic versus career enrichment benefit satisfaction. Journal of Organizational Behavior, 22(6), 669-688.

Boselie, P. (2010). High performance work practices in the health care sector: A Dutch case study. International Journal of Manpower, 31(1), 42-58.

Bratton, J., \& Gold, J. (2003). Human Resource Management Theory and Practice. Oxford: Palgrave Macmillan.

Carman, M. (2011). Organizational commitment among licensed practical nurses: exploring associations with empowerment, conflict and trust. Journal of Conflict and Trust.

Cho, S., Woods, R. H., Jang, S., S., C., \& Erdem, M. (2006). Measuring the impact of human resource management practices on hospitality firms performance. International Journal of Hospitality Management, 25(2), 262-277.

Cho, V., \& Huang, X. (2012). Professional commitment, organizational commitment, and the intention to leave for professional advancement. Information Technology \& People, 25(1), 31-54. http://dx.doi.org/10.1108/09593841211204335

Cohen, A. (1998). An examination of the relationship between work commitment and work outcomes among hospital nurses. Scandinavian Journal of Management, 14, 1-17. https://doi.org/10.1016/S0956-5221(97)00033-X

Cohen, A. (1999). The relation between commitment forms and work outcomes in Jewish and Arab culture. Journal of Vocational Behavior, 54, 371-391. https://doi.org/10.1006/jvbe.1998.1669

Cohen, A. (2007). An examination of the relationship between commitments and culture among five cultural groups of Israeli teachers. Journal of Cross-Cultural Psychology, 38, 34-49. https://doi.org/10.1177/0022022106295440 
Cohen, A. (2010). Values and commitment: A test of Schwartz's human values theory among Arab teachers in Israel. Journal of Applied Social Psychology, 40, 1921-1947. https://doi.org/10.1111/j.1559-1816.2010.00645.x

Cohen, A., \& Liu, Y. (2011). Relationships between in-role performance and individual values, commitment, and organizational citizenship behavior among Israeli teachers. International Journal of Psychology, 46, 271-287. https://doi.org/10.1080/00207594.2010.539613

Dartey-Baah, K. (2014). Organizational antecedents and perceptions of fairness in policy implementation among employees in the banking sector of Ghana. African Journal of Business Management, 8(18), 816-831.

DeCenzo, D. A., \& Robbins, S. P. (2013). Human resource management. Asia: Wiley.

Dominguez, A. A. (2011). The impact of human resource disclosure on corporate image. Journal of Human Resource Costing \& Accounting, 15(4), 279-298. http://dx.doi.org/10.1108/14013381111197225

Eisenberger, R., Huntington, R., Hutchison, S., \& Sowa, D. (1986). Perceived Organizational Support. Journal of Applied Psychology, 71, 500-507.

Fiorito, J., Bozeman, D. P., Young, A., \& Meurs, J. A. (2007). Organizational commitment, human resource practices, and organizational characteristics. Journal of Managerial Issues, 19(2), 186-207.

Fischer, R., \& Mansell, A. (2009). Commitment across cultures: A meta-analytical approach. Journal of International Business Studies, 40, 1339-1358. https://doi.org/10.1057/jibs.2009.14

Fong, C., Ooi, K., Tan, B., Lee, V., \& Chong, A. (2011). HRM practices and knowledge sharing: an empirical $\begin{array}{llll}\text { study. International Journal of } & \text { 304-723. }\end{array}$ https://dx.doi.org/10.1108/01437721111158288

Gellatly, I. R., Hunter, K. H., Currie, L. G., \& Irving, G. (2009). HRM practices and organizational commitment,. The International Journal of Human Resource Management, 20(4), 869-884.

Giauque, D., Ritz, A., Varone, F., \& Anderfuhren-Biget, S. (2010). Public service motivation first empirical evidence in Swiss municipalities. Yearbook of Swiss Administrative Sciences, 1(1), 159-170.

Gould-Williams, J. S. (2003). The importance of HR practices and workplace trust in achieving superior performance: A study of public-sector organizations. International Journal of Human Resource Management, 14(1), 28-54.

Gould-Williams, J. S., \& Gatenby, M. (2010). The effects of organizational context and team working activities on performance outcomes: A study conducted in England local government. Public Management Review, 12(6), 759-787.

Jafari, S., Afshin, T., Jafari, K., \& Barzegar, M. (2015). Evaluation of organizational commitment among nurses in Intensive Care Units. Journal of Nursing and Midwifery Sciences, 2(3), 38-43.

Jørgensen, F., \& Becker, K. (2015). Balancing organizational and professional commitments in professional service firms: the HR practices that matter. International Journal of Human Resource Management, 26, 23-41. https://doi.org/10.1080/09585192.2014.925947

Jørgensen, F., \& Sluhan, A. (2013). Exploiting family business values to create non-family employee commitment. The proceedings of the International Family Enterprise Research Academy 2013 (IFERA) Annual Conference (pp. 2-6). St. Gallen, Switzerland: IFERA.

Juhdi, N., Pa'wan, F., Hansaram, R., \& Othman, N. (2011). HR practices, organizational commitment and turnover intention: A study on employees in Klang Valley, Malaysia. Recent Researches in Applied Economics, 30-36.

Kehoe, R. R., \& Wright, P. M. (2013). The impact of high-performance human resource practices on employees' attitudes and behaviors. Journal of Management, 39(2), 366-391.

Klein, H., Molloy, J., \& Brinsfield, C. (2012). Reconceptualizing workplace commitment to redress a stretched construct: Revisiting assumptions and removing confounds. Academy of Management Review, 37, 130-151. https://doi.org/10.5465/amr.2010.0018

Larber, M., \& Savis, S. (2014). Factors affecting nurses organizational commitment . Obzornik zdravstvene Nege, 48(4), 294-301.

Lew, T. (2011). Affective organizational commitment and turnover intention of academics in Malaysia. Proceedings of the International Conference on Business and Economics Research. Kuala Lumpur: ICBER. 
McElroy, J. (2001). Managing workplace commitment by putting people first. Human Resource Management Review, 11(3), 327-335.

Meyer, J. P., \& Smith, C. A. (2000). HRM practices and organizational commitment: Test of a mediation model. Canadian Journal Of Administrative Sciences, 17(4), 319-331.

Meyer, J. P., Becker, T. E., \& Vandenberghe, C. (2004). Employee commitment and motivation: a conceptual analysis and integrative model. Journal of Applied Psychology, 89, 991-1007.

Meyer, J. P., Stanley, D. J., Jackson, T. A., McInnis, K. J., Maltin, E. R., \& Sheppard, L. (2012). Affective, normative and continuance commitment levels across cultures: a meta-analysis. Journal of Vocational Behavior, 80, 225-245. https://doi.org/10.1016/j.jvb.2011.09.005

Meyer, J., \& Allen, N. (1991). A three-component conceptualization of organizational commitment. Human Resource Management Review, 23, 190-202.

Meyer, J., \& Herscovitch, L. (2001). Commitment in the workplace: Towards a general model. Human Resources Management Review, 11, 299-326.

Meyer, J., \& Smith, C. (2009). HRM Practices and Organizational Commitment: Test of a Mediation Model. Canadian Journal of Administrative Sciences, 17, 319-334.

Mowday, R. T., Steers, R. M., \& Porter, L. W. (1979). The measurement of organizational commitment. Journal of Vocational Behavior, 14, 224-247.

Ortega-Parra, A., \& Sastre-Castillo, M. (2013). Impact of perceived corporate culture on organizational commitment. Management Decision, 51(5), 1071-1083.

Özgan, H. (2011). The relationships between organizational justice, confidence, context of Commitment, and evaluating the manager and the perceptions of conflict management at the organizational behavior. Educational Sciences: Theory \& Practice, 11(1), 241-247.

Pala, F., Eker, S., \& Eker, M. (2008). The effects of demographic characteristics on organizational commitment and job satisfaction: An empirical study on Turkish health care staff. The Journal of Industrial Relations and Human Resources, 10(2), 55-75.

Paşaoğlu, D. (2015). Analysis of the Relationship Between Human Resources Management Practices and Organizational Commitment from a Strategic Perspective: Findings from the Banking Industry. ProcediaSocial and Behavioral Sciences, 207, 315-324. https://doi.org/10.1016/j.sbspro.2015.10.101

Paul, A. K., \& Anantharaman, R. (2004). Impact of people management practices on organizational performance: analysis of a causal model. International Journal of Human Resource Management 14(7), 1246-1266.

Pfeffer, J. (1998). The human equation. Boston, Massachusetts: Harvard Business School Press.

Rhoades, L., \& Eisenberger, R. (2002). Perceived Organizational Support: A Review of the Literature. Journal of Applied Psychology, 87, 698-714.

Riveros, A. M., \& Tsai, T. S. (2011). Career commitment and organizational commitment in for-profit and non-profit sectors. International Journal of Emerging Science, 1(3), 324-340.

Rodrigues, A. C., Gondim, S. M., Bastos, A. V., \& Sakamoto, R. (2013). How To Build and Develop Organizational Entrenchment and Organizational Commitment: Qualitative Analysis of Different Trajectories of Workers. Proceedings of the 37th Annual Meeting of the Brazilian Academy of Management. Rio de Janeiro: Brazilian Academy of Management.

Samadi, A., \& Mahdavikhou, R. (2009). Impacts of managerial ethics en organizational commitment: Case of employees of Hamedan Tax Offairs head office. Tax Journal New Series, 174(52), 45-71.

Sayğan, F. N. (2011). Relationship between affective commitment and organizational silence: A conceptual discussion. International Journal of Social Sciences and Humanity Studies, 3(2), 219-227.

Sepahvand, F., Atashzadeh-Shoorideh, F., Parvizy, S., \& Tafreshi, M. (2017). The relationship between some demographic characteristics and organizational commitment of nurses working in the Social Security Hospital of Khorramabad. Electronic Physician, 9(6), 4503-4509. https://dx.doi.org/10.19082/4503.

Seyedin, H., Zaboli, R., Malmoon, Z., \& Azami, S. (2013). The relationship between ethical values and organizational commitment of staff in public and non-public hospitals. Iranian Journal of Health Sciences, 1(1), 1-7. https://doi.org/10.18869/acadpub.jhs.1.1.1 
Siew, P., Chitpakdee, B., \& Chontawan, R. (2011). Factors predicting organizational commitment among nurses in State Hospitals, Malaysia. International Islamic University of Malaysia, 10(2), 21-8.

Sripirabaa, B., \& Krishnaveni, R. (2009). Performance management systems in an Indian manufacturing sector (Partnering, monetary incentives and the alignment of organizational goals). Management Research News, 32(10), 942-952. http://dx.doi.org/10.1108/01409170910994150

Suma, S., \& Lesha, J. (2013). Job satisfaction and organizational commitment: The case of Shkodra municipality. European Scientific Journal, 9(17), 41-52.

Üsdiken, B., \& Wasti, S. A. (2009). Preaching, teaching and researching at the periphery: Academic management literature in Turkey, 1970-1999. Organization Studies, 30, 1063-1082. https://doi.org/10.1177/0170840609337952

Vratskikh, I., Al-Lozi, M., \& Maqableh, M. (2016). The Impact of Emotional Intelligence on Job Performance via the Mediating Role of Job Satisfaction. International Journal of Business and Management, 11(2), 69-91.

Wasti, S., Peterson, M., Breitsohl, H., Cohen, A., Jørgensen, F., Rodrigues, A., . . Xu, X. (2016). Location, location, location: Contextualizing workplace commitment. Journal of Organizational Behavior, 37, 613-632. https://doi.org/10.1002/job.2094

Weng, Q. X., \& Xi, Y. M. (2013). The relationship between career growth, organizational commitment and turnover intentions: a comparison between industrial clusters and non-clusters. Forecasting, 31, 23-30.

Weng, Q., \& McElroy, J. (2012). Organizational career growth, affective occupational commitment and turnover intentions. Journal of Vocational Behavior, 80, 256-265. https://doi.org/10.1016/j.jvb.2012.01.014

Weng, Q., McElroy, J. C., Morrow, P. C., \& Liu, R. Z. (2010). The relationship between career growth and organizational commitment. Journal of Vocational Behavior, 77, 391-400. https://doi.org/10.1016/j.jvb.2010.05.003

\section{Copyrights}

Copyright for this article is retained by the author(s), with first publication rights granted to the journal.

This is an open-access article distributed under the terms and conditions of the Creative Commons Attribution license (http://creativecommons.org/licenses/by/4.0/). 